\title{
Trends in Monoclonal Antibody Production Using Various Bioreactor Systems
}

\author{
I. Jyothilekshmi and N. S. Jayaprakash* \\ Centre for Bioseparation Technology (CBST), Vellore Institute of Technology (VIT), Vellore 632014, Tamilnadu, India
}

Monoclonal antibodies are widely used as diagnostic reagents and for therapeutic purposes, and their demand is increasing extensively. To produce these proteins in sufficient quantities for commercial use, it is necessary to raise the output by scaling up the production processes. This review describes recent trends in high-density cell culture systems established for monoclonal antibody production that are excellent methods to scale up from the lab-scale cell culture. Among the reactors, hollow fiber bioreactors contribute to a major part of high-density cell culture as they can provide a tremendous amount of surface area in a small volume for cell growth. As an alternative to hollow fiber reactors, a novel disposable bioreactor has been developed, which consists of a polymer-based supermacroporous material, cryogel, as a matrix for cell growth. Packed bed systems and disposable wave bioreactors have also been introduced for high cell density culture. These developments in high-density cell culture systems have led to the monoclonal antibody production in an economically favourable manner and made monoclonal antibodies one of the dominant therapeutic and diagnostic proteins in biopharmaceutical industry.

Keywords: Monoclonal antibodies, high density bioreactors, miniPERM or CELLine cell culture devices, hollow fiber bioreactors, cryogel bioreactor, fixed and fluidized bed bioreactors, wave bioreactor

Received: December 1, 2019 Accepted: March 10, 2020

First published online: March 13, 2020

*Corresponding author Phone: +91-4162202377 E-mail:nsjayaprakash@yahoo.com nsjayaprakash@vit.ac.i

pISSN 1017-7825 eISSN 1738-8872

Copyright(C) 2021 by The Korean Society for Microbiology and Biotechnology

\section{Introduction}

The requirement of monoclonal antibodies (mAbs) as therapeutic agents and also in diagnostic applications is rising continually after the successful Nobel Prize-winning discovery of hybridoma technology by Georges Kohler and Cesar Milstein in 1975. The production of safe, efficacious and affordable monoclonal antibodies in surplus quantities warrants advanced process strategies to overcome the disadvantages of conventional methods. The commercial development of monoclonal antibody for therapeutic development was established inthe early 1980s and the first approved monoclonal antibody was OKT3 for the prevention of kidney transplant rejection in 1986 [1].Attempts were also made to improve the efficiency of antibodies either by the production of chimeric monoclonal antibodies which contain murine variable regions and human Fc IgG component [2] or by producing fully human monoclonal antibodies [3]. According to Biopharma trend survey March 2019, the major portion among biopharma products in the product pipeline is monoclonal antibodies (Fig. 1) [4]. There are 31 new mAbs and 10 biosimilars that had been introduced to the market since 2013, which made the global market in a total of $51 \mathrm{mAbs}$ and 11 biosimilars at the end of 2017 [5]. Although the global market of mAbs is progressing well, there were some crucial challenges concerning $\mathrm{mAb}$ manufacturing such as the process robustness, product reproducibility, product yield, and characterization. The failure in such challenges led to the rejection of some drugs from the approved list, for example, withdrawal of the medicine Zynbryta for multiple sclerosis in March 2018 because of the symptoms of brain inflammation. It has been reported that, among the approved mAbs, the highest number of mAbs targets cancer, which is $15 \mathrm{mAbs}$ and $12 \mathrm{mAbs}$ targets hematology, followed by dermatology (9 mAbs), rheumatology ( $8 \mathrm{mAbs}$ ) and so on [5]. In 2018, twelve therapeutic antibodies which treat a variety of disease were granted approval in European Union (EU) or US, which include three for migraine prevention, two for cancer and also HIV infection. It has been reported that there are four monoclonal antibodies undergoing regulatory review which is for different therapeutic areas for triple-negative breast cancer, paroxysmal nocturnal hemoglobinuria, plaque psoriasis, and osteoporosis. It was found that almost 33 therapeutic antibodies for cancer are in the last stage pipeline of clinical studies for chronic lympholytic leukemia, diffuse large cell lymphoma, multiple myeloma, breast cancer, melanoma, bladder cancer and so on [6]. The rapid increase in the approval of $\mathrm{mAbs}$ regularly for therapeutic use puts up a need to produce sufficient quantities of $\mathrm{mAbs}$. Although the development and production of mAbs occur under strict guidelines of regulatory authorities, the use of advanced technologies and ever-increasing familiarity of mAbs will contribute their dominance in the biopharmaceutical industries. 


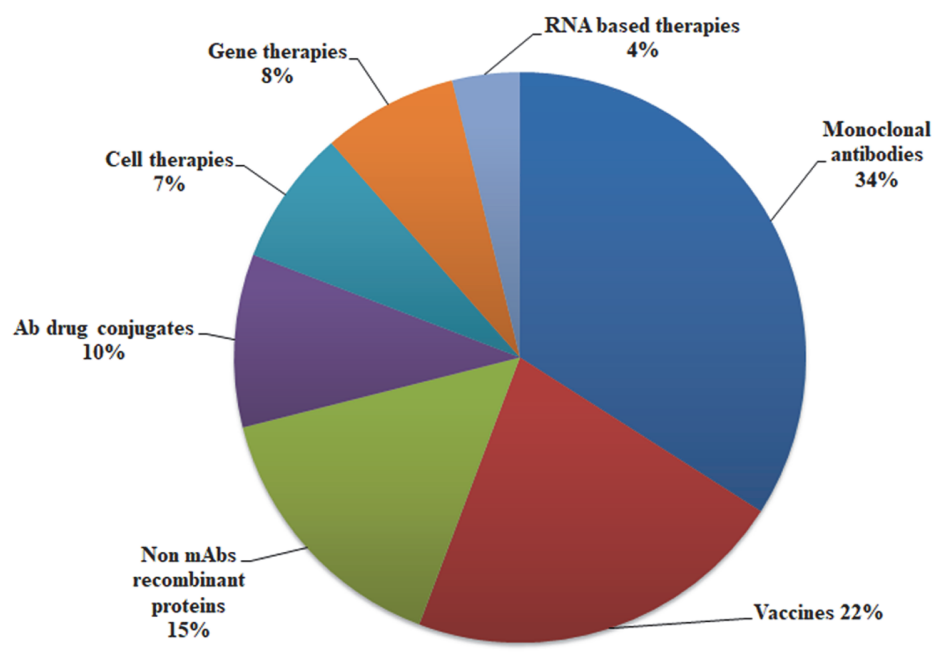

Fig. 1. Biopharma therapeutics that are currently available according to the biopharma survey conducted by NIBRT and The medicine maker (Texere publishing) in March 2019.

\section{Track to the Emergence of High-Density Cell Culture Systems}

Commercially, $\mathrm{mAbs}$ are produced in two different ways i.e. by in vivo and in vitro technology. Nowadays, the in vivo method has diminished due to animal ethical concerns. The in vitro technology, involving small-scale suspension cell culture production of mAb, utilizes devices such as T-flask, Triple flask, Cellstack, Hyper flask, spinner flasks, roller bottles and shake-flasks [7]. In these conventional systems, the monoclonal antibody concentration is limited between 10 and $100 \mu \mathrm{g} / \mathrm{ml}$, because of their low cell density. On contrary to the above mentioned conventional methods, perfusion bioreactor systems have been developed. The perfusion bioreactors are capable of providing long term culture stability for cells by continuously feeding with fresh media and removing spent media thereby eliminating the metabolic waste products which hinder cell growth. Therefore, to produce $\mathrm{mAbs}$ in higher quantities, many different types of perfusion based high cell density bioreactor systems are available. The Table 1 gives some of the examples of $\mathrm{mAbs}$, source cell line and their cultivation methods. The operating conditions of different bioreactors for the upscaling of specific monoclonal antibody production have been studied. The roller bottles, stirred tank and disposable bioreactors have been operated with both serum and serum-free media. It was found that the cells were not able to adapt to serum-free media in roller bottles and stirred tank bioreactors [12]. The highest monoclonal antibody titre was observed in a disposable static membrane bioreactor and the peak productivity was found in a stirred tank bioreactor operated in semicontinuous mode with overlay aeration [12]. Serum free medium has also been successfully used in high cell density bioreactors such as hollow fiber systems [18], packed bed reactors [19] and wave bioreactors [20] for the cultivation of mammalian cells. There is a considerable progress in cell culture techniques using serum free media, that supports the growth of hybridoma cells [21] and CHO cell lines [22, 23] for therapeutic protein production. To reduce the cost of production and to increase the output in therapeutic protein production, high-density culture $\left(\leq 10^{7}\right.$ cells $\left./ \mathrm{ml}\right)$ systems have been introduced. Eventually, the production of monoclonal antibodies with high cell density and good cell viability has become the need of the hour and this review focuses on popularized high cell density culture systems for monoclonal antibody production.

According to the property of cell lines, they can be either cultured in suspension or adherent culture.

Table 1. Monoclonal antibodies, source cell line and cultivation method.

\begin{tabular}{|c|c|c|c|c|}
\hline Sl. No & Antibody & Host cell line & Culture system & Ref \\
\hline 1 & RF-HBs-1(Anti HBs Ag mAb) & Hybridoma & Perfusion & {$[8]$} \\
\hline 2 & CB72.3 Chimeric IgG4 & GS-CHO 46 & Fed Batch /Perfusion & {$[9]$} \\
\hline 3 & Alemtuzumab(Anti CD 52 mAb) & $\mathrm{CHO}$ & Perfusion & [10] \\
\hline 4 & Anti IL-8 mAb & $\mathrm{CHO}$ & Shake flask / wave bag & [11] \\
\hline 5 & Anti-Salmonella Enteritidis O-Ag mAb & Hybridoma & $\begin{array}{l}\text { Roller bottles/Stirred tank/ } \\
\text { Disposable bioreactor }\end{array}$ & [12] \\
\hline 6 & $\begin{array}{l}\text { 100F } 4 \mathrm{mAb} \text { (specific to HA protein of } \\
\mathrm{H} 1 \mathrm{~N} 1 \text { influenza) }\end{array}$ & Drosophila Schneider 2 & Perfusion & [13] \\
\hline 7 & Anti enrofloxacin IgG1 mAb & Hybridoma & Batch/Fed Batch/Perfusion & [14] \\
\hline 8 & CRL-1606 (Anti fibronection IgG mAb) & Hybridoma & Batch/Fed Batch & [15] \\
\hline 9 & Anti digitoxin IgG & Hybridoma & Batch/perfusion & [16] \\
\hline 10 & Anti CD22 $\operatorname{IgG}_{2} \mathrm{a}$ & $\mathrm{SP}_{2 / 0}$ & Batch/Fed Batch/Perfusion & [17] \\
\hline
\end{tabular}


Accordingly, a copious amount of work has been done for the suspension culture of cell lines in stirred tank bioreactor for monoclonal antibody production. The perfusion mode culture in the stirred tank reactor with the ceramic membrane as a cell retention device was used for the production of IgG $2 \mathrm{a} \mathrm{mAb}$. The maximum cell count was reported to be $3.5 \times 10^{7}$ cells $/ \mathrm{ml}$ and the cell viability was found to be $95 \%$ such that when this system is used with micro-carriers or porous microspheres or perfusion technique, the cell density will reach up to $10^{7}$ cells $/ \mathrm{ml}$ [24]. Another study reported that stirred tank bioreactors are widely used for the production of mAbs in industrial large-scale for cell lines like CHO, hybridoma, and NSO. The perfusion mode of culture with stirred tank bioreactors using spin filters significantly resulted in high volumetric production of $\mathrm{mAb}$ which is specific for endofloxacin with a yield of $61.4 \mathrm{mg} /$ day and achieved the cell viability of $1.57 \times 10^{6} \mathrm{cells} / \mathrm{ml}$ within 5 days [14]. Some cell lines are incapable of growing in suspension; for such cell lines, the high cell density, low volumetric systems are available which means that cells can achieve high cell density in a small volume.

Although the stirred tank bioreactors could be considered as high cell density culture bioreactors, the hybridoma cell lines could not bear the shear stress by suspension media agitation. Therefore, it is important to improve the techniques for immobilizing cells to porous beads. Cells are usually immobilized by adsorption or entrapment in high cell density culture systems. The size, porosity and surface characteristics of the matrix determine the efficacy of cell adsorption. The matrices could be natural/synthetic or may require some chemical modifications for the adsorption of cells. Packed bed and polymer-based bioreactors systems have been typically used for the immobilization of cells for cultivation. A high cell density culture system renders compact bioreactors with high volumetric production, although these systems are difficult to operate [25].

\section{High Cell Density Culture Systems}

\section{Hollow Fiber Bioreactor}

The first description of the hollow fiber bioreactor (HFBR) was given by Knazek et al. [26], which showed that mammalian cells were able to attach to the hollow fiber and grow in vitro. This approach has many advantages, it can attain the cell density similar to the growth of solid tissues in vivo and cells could be maintained in a more physiological state concerning nutrient supply, waste removal, and $\mathrm{pH}$ control.

The hollow fiber perfusion bioreactor is a continuous perfusion culture system, containing a set of thousands of semipermeable hollow fibres of $200 \mu \mathrm{m}$ diameter in a parallel array within a cartridge with inlet and outlet ports (Fig. 2). The cells are placed on the outside of the fiber in the extra capillary space where they can attach and grow. The cell culture medium is continuously circulated through the interior of the fibres to provide nutrients and for oxygenation and hollow fibres allow nutrients and metabolic waste products to diffuse both the ways across the fiber walls. A wide range of materials is used for the hollow fibres like polysulfone and cellulose derivatives, which are hydrophilic and have high percent porosity. The molecular weight cut-off begins at $5 \mathrm{kDa}$ and goes up to virtually any desired limit. Hollow fibers provide a high surface to volume ratio of $200 \mathrm{~cm}^{2} / \mathrm{ml}$ [27] and allow a large number of cells to attach in a small volume. Due to the avoidance of nutrient inadequacy and accumulation of toxic metabolites, cells can achieve a high cell density of $10^{9}$ cells $/ \mathrm{ml}$. Antibodies can be produced from a single cartridge for more than six months in continuous culture mode. In a study, the production of antibody fragments in hollow fiber bioreactors resulted in the antibody harvest around 137 to $307 \mathrm{mg}$ in the crude extract. The further purification protocol, which includes hydroxy-appetite and ion-exchange chromatography, showed a good recovery of 50 to $150 \mathrm{mg}$ of purified antibody fragments [33]. In hollow fiber bioreactors, the cells are also allowed to culture in reduced serum or serum-free medium which facilitates the product for the convenient purification [28-30]. Accordingly, with serum-free medium it was possible to run the hollow fiber bioreactor for forty three days. The $\mathrm{mAb}$ production was $11 \mathrm{mg} /$ day and the maximum amount of IgG obtained was about $2.4 \mathrm{mg} / \mathrm{ml}$ [31].

As the cells grow in high densities, the nutrients must be transferred across the layer of cells, so the mass transfer that occurs due to diffusion is limited to several cells. Subsequently, many efforts have been made to modify the design of HFBR, because of their popularity in high-density culture systems. The development of the axial flow HFBR system was one of the breakthroughs in the HFBR development. To overcome the limitations of mass convection transport by the previous system, a new approach called tricentric HFBR has been developed. As compared to the conventional HFBR, tricentric HFBR offers a third compartment that is meant for immobilized cells and the other two compartments, namely intra and extra capillary compartments are dedicated for medium flow.As an alternative to conventional HFBR, a new system called micro HFBR has also been developed. It consists

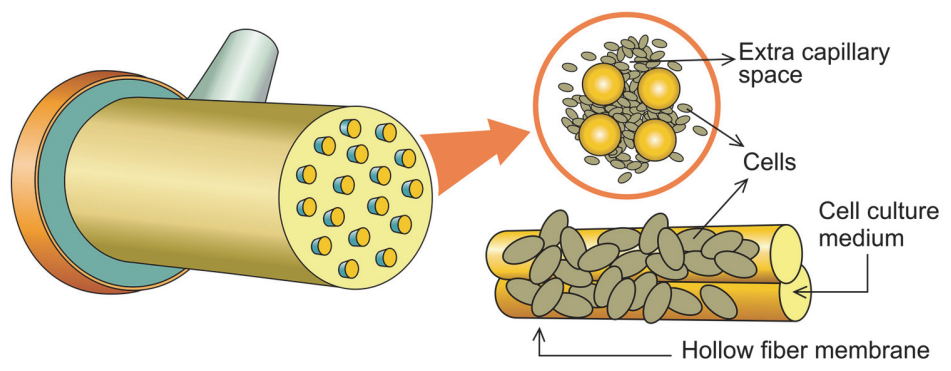

Fig. 2. Representation of hollow fiber bioreactor which consists of a bundle of fibres and media circulated within capillaries while cells are grown in the extra capillary space. 
of fibers that are implanted inside silicon tubing where the cells are seeded inside the fibers and the extra capillary space between the fibers and silicon tubing is satisfactory for medium supply.

Another HFBR called Fiber Cell systems have been introduced, which consist of hydrophilic polysulfone fiber for good cell culture performance with MWCO of $5 \mathrm{kDa}$ and $20 \mathrm{kDa}$ [32]. One unique feature of the Fiber Cell system is that the fibers are cast with little waves, which result in even distribution of the fiber bundles within the cartridge shell. These waves push against one another to produce uniform fiber bundles, by eliminating channelling effect by the fiber spacing. Hollow fiber bioreactors are permissible for both evaluation of scale-up and also for non-affinity based purification protocol.

Hollow fiber bioreactors have vast amount of applications in industrial aspect in the near future, as those are highly efficient and compact. The HFBs are highly economical for virus cultivation and also for toxicology studies in vitro, which helps to model the availability of drugs and dosage. Studies are on-going with hollow fibres in the field of tissue engineering to utilise their property of biocompatibility with the cells. The surface property of hollow fibers facilitates the stem cell expansion, 3D culture and engineering of soft tissues.

The introduction of dialysis membrane-based bioreactors, namely MiniPERM and CELLine 1000 had been also used for high-density cell culture. The MiniPERM bioreactor consists of two chambers separated by a dialysis membrane. These two chambers are the production module and supply module for antibody production and medium supply respectively. The outside of the production module is made up of silicon tubing which helps in the exchange of gas and nutrients and low molecular weight compounds pass across the dialysis membrane by diffusion; whereas, in CELLine system, the operation of the system is simple like a tissue culture flask. These systems consist of a dialysis membrane of $10 \mathrm{kDa}$, which separates the cell compartment from medium reservoir. The silicon membranes on the base of the cell compartment facilitate gas exchange. Both the dialysis membranebased bioreactor systems reach the cell density of about $10^{7}$ to $10^{8}$ cells $/ \mathrm{ml}$, which is about two times higher than the one obtained from conventional cell culture methods.

\section{Fixed and Fluidized Bed Bioreactors}

Earlier studies with fixed and fluidized bed reactors focussed on the production of therapeutic proteins as an alternative to hollow fiber bioreactors. These systems have been successfully used for many cell lines for the viral construct in gene therapy and also the cultivation of cell lines such as hybridoma, CHO, VERO, etc. In the case of fixed and fluidized bed reactors, the systems consist of a column filled or packed with microcarrier beads for the support where the cells get immobilized (Fig. 3). In detail, these microcarrier beads are retained in a cylindrical vessel, through which the media circulates. In fixed-bed systems, the microcarriers are packed in a column whereas, in fluidized systems, the microcarrier porous beads float in a column. The column is continuously perfused with media from the reservoir. They have been successfully applied for the long term production of monoclonal antibodies. The most commonly used porous microcarriers in packed bed systems are Fibra-Cel and SIRAN. Fibra-Cel microcarrier beads can achieve cell density and productivity ten times higher as compared to conventional methods. It has been reported that these types of microcarrier systems can contain cells up to the density of $10^{8}$ cells $/ \mathrm{ml}$ even in serum-free media [34]. Cytoline (GE healthcare) is the microcarrier most commonly used in fluidized bioreactor systems which achieves the cell density of $2 \times 10^{8} \mathrm{cell} / \mathrm{s} / \mathrm{ml}$. Cytopilot Mini is a fluidized bioreactor that uses the cytoline as a microcarrier and capable of producing $50 \mathrm{mg} / \mathrm{l}$ of monoclonal antibodies in a running culture for 60 days. The microbeads packed in a vessel with continuous media supply could achieve high cell density, high metabolic activity, and homogeneous cell distribution. Recent studies which have carried out with fluidised bed systems showed their importance in present and future of bioprocessing technology. Fluidised bed bioreactors have improved in a way to minimize the void volume in the microcarrier beads. In this process, microcapsule suspension fluidised system has been developed, which resulted in high viability percentage and there by improved the productivity [35]. In another study, centrifugal bioreactors have been developed similar to fluidized bed bioreactor. In centrifugal bioreactor systems, the cells were immobilized

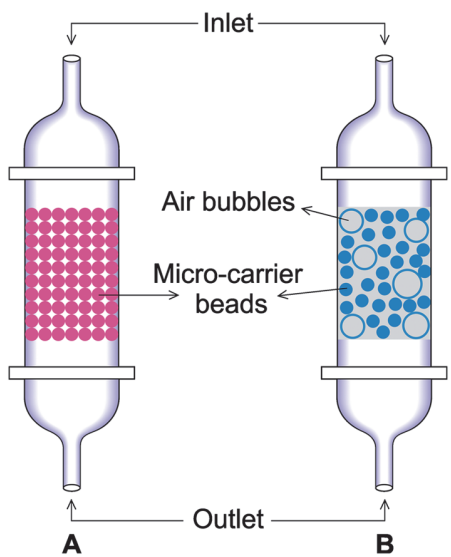

Fig. 3. Schematic representation of fixed and fluidized bed reactor systems with cells immobilized over micro-carrier beads (A) Fixed bed reactor (B) Fluidized bed reactor. 
on to the microcarrier beads by centrifugal force, which achieved high cell density and good cell viability also. It is reported that the cell density increases up to 1.7 times approximately when the centrifugal force is doubled [36].These studies reveal that, the fixed and fluidised bed bioreactor systems become one of the pioneers in bioprocessing in the future.

\section{Wave Bioreactor}

These bioreactors are efficient, cost-effective systems in bioprocessing and this reactor has been tested for cell lines like hybridoma cells, CHO cells, NSO cells and also insect cells. Wave bioreactors are a kind of disposable bioreactors, designed by Singh for the cultivation of mammalian cells [37]. The structure of the wave bioreactor consists of a disposable chamber called cell bag, which contains the cell culture medium, cells and also a port of air circulation (Fig. 4). The mixing and agitation are enhanced by the rocking motion of the chamber backward and forward, which leads to efficient mass transfer. Hence, the resulting ambient environment for cell growth can achieve a cell density over $1 \times 10^{8}$ cells $/ \mathrm{ml}$ and this system can be scaled up to $1,000 \mathrm{~L}$. In this kind of wave bioreactor, the cells are inoculated into two-in-one cell bags, where cell growth and antibody production can be monitored separately for batch and perfusion cultures. Thus, maximum cell viability in perfusion mode was found to be $1.04 \times 10^{4}$ cells $/ \mathrm{ml}$ and antibody production was $1,437 \mathrm{mg} / \mathrm{l} \cdot$ day. Recent studies carried out with the wave bioreactors showed that, these systems are apt for virus cultivation [38], insect cell cultivation [39], expansion of embryonic cells etc. Eventually, the wave bioreactors will have a future outlook for the production of high value proteins from virus, which are difficult for upstream processing.

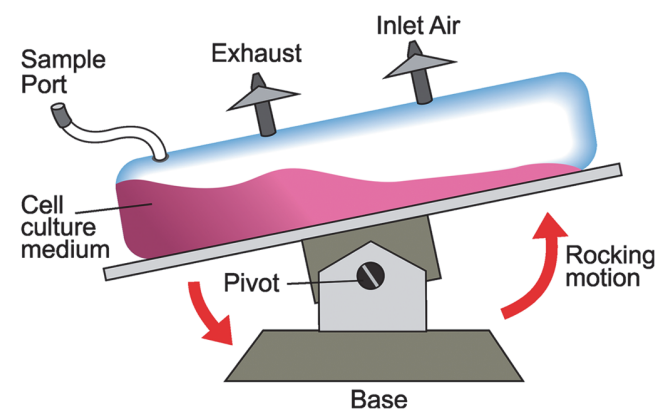

Fig. 4. Schematic representation of wave bioreactor, tilting along a pivot axis causing the movement of cell culture medium with cells by rocking motion.

\section{Cryogel Bioreactors}

The vital necessity of developing economically favourable bioreactors in both lab-scale and industrial level leads to the debate of disposable bioreactor systems. Cryogel bioreactor is a disposable, esteemed, high cell density perfusion bioreactor, which gives a long productive lifetime for cells. It has been described for long term continuous production of therapeutic proteins [40-42]. The bioreactor consists of a polymeric cryogel as a matrix for the cultivation of cells, medium reservoir and peristaltic pump (Fig. 5). Cryogels are three-dimensional polymeric scaffolds formed at subzero temperature by polymerization of monomers or by polymeric precursor by the phenomenon of cryogelation, which consists of an interconnected network of macropores. Cryogelation technique has an advantage that the cryogels can be made in different sizes and shapes like disc, sheets or monoliths with varying dimensions. The polymer-based cryogel has several advantages over other kinds of gels

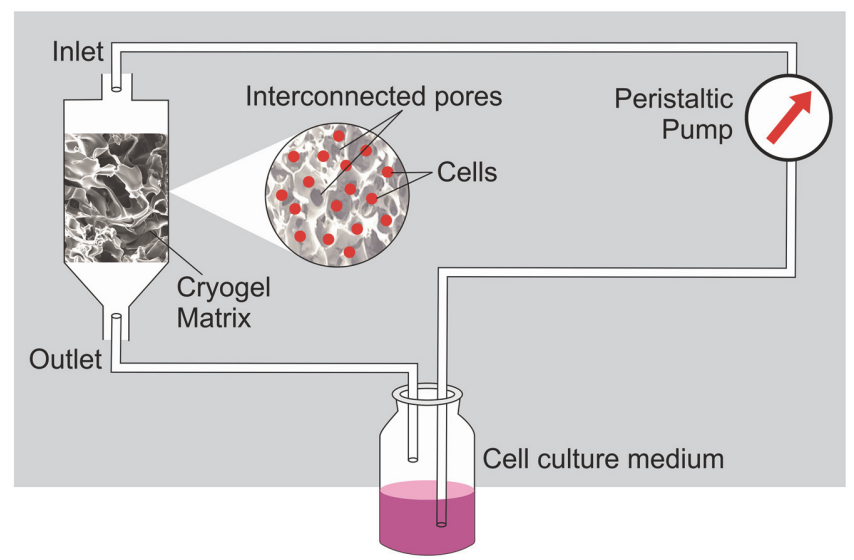

Fig. 5. Diagrammatic representation of cryogel bioreactor, where cells are entrapped into the pores of the cryogel matrix and replenished by the continuous mode of the medium supply. 
i.e., simple approach by which they can be synthesized,use of aqueous solvent for their synthesis and unique combination of high porosity with adequate mechanical strength and osmotic stability. The size of these macropores varies from few micrometers to $100 \mu \mathrm{m}$, which allows the unhindered convectional mass transfer. This makes cryogels an ultimate support for cell immobilization and proliferation. The hybridoma cell lines are adsorbed to the inner pore walls of cryogel matrices which are covalently immobilized with gelatin. The coating with gelatin enhances the adherence of cells to the matrices. The cells are situated in such a microenvironment which makes sure that there is virtually no barrier that arises for easy diffusion of substrates and metabolites [43, 44]. As observed in the literature, it has been reported that a bioreactor with polyacrylamide based cryogel was run in continuous mode for 55 days and obtained monoclonal antibody productivity of $130 \mu \mathrm{g} / \mathrm{ml}$ on the $36^{\text {th }}$ day [42].

The future advances of cryogel matrices are relayed on their property of being biocompatible with any cell line. Hence, cell based therapies require enormous number of cells with cell density ranging from $10^{8}$ to $10^{10}$. Cryogel matrices are the efficient platform to grow large quantity of cells in order to avoid the restriction of space required for the growth of cells because of their high surface area. In addition to that, the studies regarding microfluidic bioreactors with cryogels is also on-going, that will make the future brighter for the $3 \mathrm{D}$ modelling of cells, followed by 'organ on a chip' technology. Therefore, the establishment of such low investment platforms will have significant benefits on understanding disease development and drug modelling. Apart from the cell culture applications, cryogel bioreactors have also been used for industrial production of biomolecules. In a study, cryogels were immobilised with $\alpha$-amylase for starch hydrolysis for the industrial production of maltose [45]. Those studies are the forthcoming indication for the acceptance of cryogel bioreactors in industrial production of various biomolecules.

\section{Recent Developments in High Cell Density Culture Systems}

To improve the performance of high cell density bioreactors, a considerable amount of work has been done by utilizing new technologies. Some of the bioreactors which have been working at high cell density are listed in Table 2. In case of productivity, major improvements have been done in two different aspects. One of them is to improve the cellular productivity by modification in the growth environment $[52,53]$ and the other method is to increase the volumetric productivity where the cell density is relevant $[54,55]$. Significant efforts have been made with some studies providing insights into the use of bioinformatics tools for the upmarket production of monoclonal antibodies. One of them is the designing of $3 \mathrm{D}$ nylon beads for cell immobilization studies. Thus, this technique could utilize 3D nylon beads of different bead sizes of 15 to $30 \mathrm{~nm}$ with a varying pore size $(0.6,1$, and $1.5 \mathrm{~mm}$ ). The use of such 3D beads provided easiness in handling and saved the time and resources [56]. The computational analysis was exploited for the modelling of a high-performance agent band to create changes in different variants of cell culture to simulate mammalian cell culture bioreactor with the notified increase in cell viability [57].

Proteomics had also provided some new insights into bioreactors processing and enhanced the production of therapeutic proteins. It is important to identify the parameters which affect the production of a particular protein. Further studies revealed that the monitoring of the parameters with microarray-based MALDI-TOF had achieved the production of monoclonal antibodies with high quality at the end, which could guide further processing in biopharma [58].

Many factors affect the proliferation of high cell density cultures including $\mathrm{pH}$, temperature, dissolved oxygen, nutrient consumption, metabolic accumulation, serum growth factor, extracellular matrix, etc. It was possible to improve the robustness, high cell viability and also high productivity through high cell density by a small change in the $\mathrm{pH}$ in perfusion culture [10]. In another study, to boost up the monoclonal antibody production with $\mathrm{CHO}$ cell lines, the $\mathrm{pH}$ of cell culture media was optimized for $\mathrm{pH}$ control strategy using $\mathrm{pH}$-dependent dynamic model. This process of $\mathrm{pH}$ shift towards the proper range suitable for the $\mathrm{CHO}$ cell lines resulted in a $40 \%$ increase in the monoclonal antibody production [59]. Likewise, cell culture media contributes a major role in cell viability and product quality. The optimization of cell culture media through the supplementation of various amino acids showed improved production of monoclonal antibodies. It has been shown that the amino acid input to the cell

Table 2. High cell density bioreactor systems for monoclonal antibody production.

\begin{tabular}{|c|c|c|c|c|c|}
\hline $\begin{array}{c}\text { Type of } \\
\text { bioreactor }\end{array}$ & $\begin{array}{l}\text { Cell density } \\
\text { (Cells/ml) }\end{array}$ & $\begin{array}{l}\text { Period } \\
\text { of run } \\
\text { (Days) }\end{array}$ & Advantages & Disadvantages & Ref. \\
\hline Hollow fiber & $1-2 \times 10^{8}$ & 30 & • Reduces serum requirement & - Membrane fouling & [46] \\
\hline bioreactor & & & $\begin{array}{l}\text { - Increase in secretary product } \\
\text { concentration(10X to } 100 \mathrm{X}) \\
\text { - Cells grow post fluently for months }\end{array}$ & $\begin{array}{l}\text { - Fiber breakage } \\
\text { - Difficult to monitor }\end{array}$ & [47] \\
\hline Wave bioreactor & $0.3-1.5 \times 10^{8}$ & 27 & $\begin{array}{l}\text { - Flexibility } \\
\text { - Minimum time and cost }\end{array}$ & $\begin{array}{l}\text { - Non customisable } \\
\text { - Restricted scale up }\end{array}$ & [48] \\
\hline - Fixed bed reactor & $5 \times 10^{7}-1 \times 10^{8}$ & 24 & - Easy to build & - Increased vessel size & [49] \\
\hline $\begin{array}{l}\text { - Fluidised bed } \\
\text { reactor }\end{array}$ & $5 \times 10^{8}$ & 24 & $\begin{array}{l}\text { - Low cost of construction,operation } \\
\text { and maintenance }\end{array}$ & $\begin{array}{l}\text { and pressure drop } \\
\text { Erosion of internal } \\
\text { components }\end{array}$ & {$[50]$} \\
\hline Cryogel bioreactor & $1 \times 10^{7}-1 \times 10^{8}$ & $55-60$ & $\begin{array}{l}\text { - High biocompatibility } \\
\text { - Cells are resistant to degradation } \\
\text { - Non-toxic }\end{array}$ & - Non reusable & {$[51]$} \\
\hline
\end{tabular}


media leads to the high cell density of $\mathrm{CHO}$ cell lines and produced good metabolic profiles [60].

Apart from the modification with the cell culture parameters, the existing high cell density bioreactors have been renovated in many aspects from the past ten years. Eventually, a new concept of bioreactor named cell tank has been introduced, which is a disposable mode of bioreactor for perfusion mode of culture. It can be used for both adherent and non-adherent cell lines at high cell density and consists of a non-woven polyester matrix caged in a cassette and immersed in a reservoir. Cells are entrapped in the matrix and the media circulates through it [61]. A novel bioreactor system has also developed recently which mimic the scale down perfusion culture. This system studied the cell retention by sedimentation, and then cell culture supernatant was removed and replenished with fresh media. This approach could obtain good cell densityand also could reduce the cell culture media requirements up to 80 fold [62].

Hollow fiber bioreactors are one of the most influencing systems in high cell density culture. Recent advancements in the field of hollow fiber bioreactors aided in improved production of therapeutics. Microfiltration based hollow fiber bioreactors were developed which consist of two hollow fibers inserted in a vessel, which could able to remove low molecular weight inhibiting metabolites without removing the cells [63]. A crossed hollow fibre membrane bioreactor consists of two types of fibres with a different molecular weight cut off (MWCO) which also possesses entirely different physicochemical properties [64]. Hollow fibres have the disadvantage of membrane fouling, which further reduces the life of the same. In order to reduce this issue, studies have been carried out to develop hollow fibres with large pore size. The development of such hollow fiber systems with large pore size could offer good cell retention while allowing complete passage of product with achievement of high cell density [65].

The hollow fiber bioreactors and membrane bioreactors have some common disadvantages like the risk of contamination, clogging of cells in the membrane; difficulty in monitoring, which led to the development of matrices for the immobilization of cells. Among the high cell density culture systems where the matrices have been used for cell immobilization, the contribution of cryogel bioreactors was boundless. In one study, poly-D-lysine was used for cell adhesion in microfluidic chips for the hybridoma cell lines, which provided good cell viability and long term culture stability [66]. Gelatin has been also used for coating over the cryogel inner walls for cell adhesion. Cryogel bioreactors are well admired in many studies for the production of therapeutic proteins including monoclonal antibodies. The major advantage was that cryogels matrices consisting of different polymeric blends could be prepared. Therefore, cryogel matrices could be prepared by a combination of chemically different monomers which yielded the cryogel's surfaces either charged or uncharged. The ease of preparing cryogels at different shapes also made the drift towards cryogel bioreactors for high cell density and long term culture stability [67]. Eventually, cryogel bioreactors have been used for the upscaling of many mAbs and also for other purposes like wastewater treatment and in vitro model for cancer metastasis studies [68]. The ease and handling of cryogel matrices broaden their applications in different fields like bioseparation, tissue engineering, etc. Especially in cell culture, cryogel matrices were used as 3D support for cells to study their growth parameters especially from cancer cell lines [69] and bone cells. Subsequently, in a recent research study, cryogels were used for the storage and transportation of mammalian cells. The cell viability was found to be approximately 1.5 times higher in comparison with suspension culture and the duration of cryopreservation in cryogel matrices doesn't affect the cell viability [70].

Many attempts have also been made in the case of wave bioreactors. In particular, the perfusion culture using a wave bioreactor was demonstrated for the production of human monoclonal antibody from Drosophila Schneider 2 cells [13]. The perfusion mode operation of wave bioreactor using microfiltration or ultrafiltration by altering tangential flow (ATF) or tangential flow filtration (TFF) leads to the growth of CHO cell lines up to $10^{8} \mathrm{cells} / \mathrm{ml}$ after twelve days and $\mathrm{mAb}$ production was found to be six times higher [48]. The introduction of low-intensity pulsed ultrasound to wave bags increased the production of $\mathrm{mAb}$. It was found that five minutes of ultrasound treatment increases the antibody titre up to 25\% [11]. In another example, a new technology-based 2D rocking bioreactor has been established and utilized for recombinant protein production. It is a CELL-tainer bioreactor system and is an alternative to the stirred tank reactors for the bioprocessing centered on microbial platforms [71].

In the biopharma industry, to speed up the ever-present drive to increase the product yield, it is necessary to improve the existing systems for both manufacturing and upstream processing. Thus, significant efforts have been made for upgrading the processes for the monoclonal antibody production and also to increase the efficiency of the existing processes. High-density cell culture systems provide high volumetric productivity and that bioreactor system seems to be perfect for both anchorage-dependent and suspension cultures. The entry of porous matrix for cell immobilization leads to a potential peak in the graph of therapeutic protein production. Cryogel based bioreactors are one among the disposable bioreactors, which provide significantly large surface area for cell immobilization thereby elicit higher monoclonal antibody production in lab-scale and commercial production. Also, the productivity of cryogel based bioreactors is equally comparable with that of hollow fiber bioreactors.

\section{Acknowledgments}

The first author likes to extend her warm gratitude towards DST-INSPIRE, Government of India for providing the Senior Research Fellowship stipend during the study. The authors thank Prof. M.A. Vijayalakshmi, Founder Director, Centre for Bioseparation Technology, VIT, Vellore, for providing the support. The authors also thank the Department of Science and Technology, Government of India, and VIT, Vellore for providing the facilities. 


\section{Conflict of Interest}

The authors have no financial conflicts of interest to declare.

\section{References}

1. Abramowicz D, Schandene L, Goldman L, Michel G, Alain C, Pierre V, et al. 1989. Release of tumour necrosis factor, Interleukin-2 and gamma interferon in serum after injection of OKT3 monoclonal antibody in kidney transplant recipients. Transplantation 47: 606-608.

2. Boulianne GL, Hozumi N, Shulman M J. 1984. Production of functional chimeric mouse/human antibody. Nature 312: 643-646.

3. Cole SP, Campling BG, Atlaw T, kozbor D, Roder J C. 1984. Human monoclonal antibodies. Mol. Cell. Biochem. 62: 109-120.

4. NIBRT and The Medicine maker (Texere Publishing). 2019. Trends in Biopharma manufacturing survey report. Available from https://www.nibrt.ie/wp-content/uploads/2019/03/Biopharma_Trends_Survey_Mar19.pdf. Accessed Oct. 17, 2019

5. Grilo AL, Mantalaris A. 2019. The increasing human and profitable monoclonal antibody market. Trends Biotechnol. 37: 9-16.

6. Helene K, Janice MR. 2018. Antibodies to watch in 2019. MAbs 11:219-238.

7. Baron D. 1990. Industrial production of monoclonal antibodies. Naturwissenschaften 77: 465-471.

8. Bartley A, Macleod A J. 1992. A comparative study of monoclonal antibody yield using batch, continuous or perfusion suspension culture techniques. pp. 376-378.

9. Goey C H, Bell D, Kontoravdi C. 2019. CHO cell cultures in shake flasks and bioreactors present different host cell protein profiles in the supernatant. Biochem. Eng. J. 144: 185-192.

10. Zheng C,Zhuang C, Chen Y, Fu Q, Qian H, Wang Y, et al. 2017. Improved process robustness, product quality and biological efficacy of an anti-CD52 monoclonal antibody upon $\mathrm{pH}$ shift in Chinese hamster ovary cell perfusion culture. Process Biochem. 17: 13595113.

11. Zhao Y, Xing J, Xing JZ, Ang WT, Chen J. 2014. Applications of low-intensity pulsed ultrasound to increase monoclonal antibody production in CHO cells using shake flasks or wavebags. Ultrasonics 54: 1439-1447.

12. Ayyildiz-Tamis D, Nalbantsoy A, Elibol M, Gurhan S D. 2014. Effect of operating conditions in production of diagnostic Salmonella Enteritidis O-antigen-specific monoclonal antibody in different bioreactor system. Appl. Biochem. Biotechnol. 172: 224-236.

13. Wang L, Hu H, Yang J, Wang F, Kaisermayer C, Zhou P. 2012. High yield of human monoclonal antibody produced by stably transfected drosophila schneider 2 cells in perfusion culture using wave bioreactor. Mol. Biotechnol. 52: 170-179.

14. Komolpis K, Udomchokmongkol C, Phutong S, Palaga T. 2010. Comparative production of a monoclonal antibody specific for enrofloxacin in a stirred tank bioreactor. J. Ind. Eng. Chem. 16: 567-571.

15. Xie L, Wang DI. 1992. High cell density and high monoclonal antibody production through medium design and rational control in a bioreactor. Biotechnol. Bioeng. 51: 725-729.

16. Golmakany N, Rasaee MJ, Furouzandeh M, Shojaosadati SA, Kashanian S, Omidfar K. 2005. Continuous production of monoclonal antibody in a packed-bed reactor. Biotechnol. Appl. Biochem. 3: 273-278.

17. Yang JD, Angelillo Y, Chaudhry M, Goldenberg C, Goldenberg DM. 2000. Achievement of high cell density and high antibody productivity by a controlled-fed perfusion bioreactor process. Biotechnol. Bioeng. 69: 74-82.

18. Lubberstedt M, Muller-Vieira U, Biemel KM, Hoffmann SA, Knospel F, Wonne EC, et al. 2012. Serum free culture of primary human hepatocytes in a miniaturized hollow fiber membrane bioreactor for pharmacological in vitro studies. J. Tissue Eng. Regen. Med. 9: 1017-1026.

19. Meuwl F, Von Stockar U, Kadouri A. 2004. Optimization of the medium perfusion rate in a packed-bed bioreactor charged with $\mathrm{CHO}$ cells. Cytotechnology 46: 37-47.

20. Haldanker R, Li D, Saremi Z, Baikalov C, Deshpande R. 2000. Serum-free suspension large scale transient transfection of CHO cells in WAVE bioreactors. Mol. Biotechnol. 34: 191-200.

21. Manna LA, Febo TD, Armillotta G, Luciani M, Ciarelli A, Salini R, et al. 2015. Production of monoclonal antibodies in serum free media. Monoclon. Antib. Immunodiagn. Immunother. 34: 278-288.

22. Zhang H, Wang H, Liu M, Zhang T, Zhang J, Wang X, et al. 2013. Rational development of a serum free medium and fed-batch process for a GS-CHO cell line expressing recombinant antibody. Cytotechnology 65: 363-378.

23. Miki H, Takagi M. 2015. Design of serum-free medium for suspension culture of CHO cells on the basis of general commercial media. Cytotechnology 67: 689-697.

24. Hamel JP, Dong H, Tang Y, Ohashi R. 2005. A perfusion culture system using a stirred ceramic membrane reactor for hyperproduction of IgG2a monoclonal antibody by hybridoma cells. Biotechnol. Prog. 21: 140-147.

25. Ozturk SS. 1996. Engineering challenges in high density cell culture systems. Cytotechnology 22: 3-16.

26. Knazek RA, Gullino PM, Kohler PO, Dedrick RL. 1972. Cell culture on artificial capillaries: an approach to tissue growth in vitro. Science 178: 65-66.

27. Era Jain, Ashok Kumar. 2008. Upstream processes in antibody production: evaluation of critical parameters. Biotechnol. Adv. 26: 4672.

28. Kuhn J, Molle K, Brinkmann T, Gotting C, Kleesiek K. 2003. High density tissue- like cultivation of JAR choriocarcinoma cells for the invitro production of human xylosyl transferase. J. Biotechnol. 103: 191-196.

29. Marya IC, Julio AL, Richard JG. 2001. Solving design equation for a hollow fiber bioreactor with arbitrary kinetics. Chem. Eng. J. 84: 445-461.

30. Dhainaut N, Bihoreau N, Meterreau JL, Lirochon J, Vincentelli R, Mignot G. 1992. Continuous production of large amount of monoclonal immunoglobulins in hollow fiber using protein-free medium. Cytotehnology 10: 33-41.

31. Valdes R, Ibarra N, Gonzalez MM, Alvarez T, Garcia J, Liambias R, et al. 2001. Hep-1 hybridoma growth and antibody production using protein free medium in a hollow fiber bioreactor. Cytotechnology 35: 145-154.

32. Cadwell JJ. 1995. New developments in hollow fiber cell culture. Curr. Pharm. Biotechnol. 6: 397-403.

33. Yazaki PJ, Shively L, Clark C, Cheung C, LE W, Szpikowsa B, et al. 2001. Mammalian expression and hollow fiber bioreactor production of recombinant anti-CEA diabody and minibody for clinical applications. J. Immunol. Methods 253: 195-208.

34. Wang G, Zhang W, Jacklin C, Freedman D, Eppstain L, Kadouri A. 1992. Modified CelliGen-packed bed bioreactors for hybridoma cell cultures. Cytotechnology 9: 41-49.

35. Lu J, Zhang X, Li J, Yu L, Chen E, Zhu D, et al. 2016. A new fluidized bed bioreactor based on diversion-type microcapsule suspension for bioartificial liver systems. PLoS One 11: e0147376.

36. Detzel CJ, Van Wie BJ, Ivory CF. 2010. Fluid flow through a high cell density fluidized-bed during centrifugal bioreactor culture. Biotechnol. Prog. 26: 1014-1023.

37. Singh V. 1999. Disposable bioreactor for cell culture using wave-induced agitation. Cytotechnology 30: 149-158.

38. Irons SL, Chambers AC, Lissina O, King LA, Posse RD. 2018. Protein production using baculovirus expression system. Curr. Prooc. Protein Sci. 91: 1-22. 
39. Decarli MC, Dos santos DP, Astray RM, Ventini monterio DC, Calil Jorge SA, Correia D M, et al. 2018. Drosophila S2 cell culture in a wave bioreactor: potential for scaling up the production of the recombinant rabies virus glycoprotein. Appl. Microbiol. Biotechnol. 102: 4773-4783.

40. Bansal V, Roychoudhary PK, Mattiason B, Kumar A. 2006. A recovery of urokinase from integrated mammalian cell culture cryogel bioreactor and purification of enzyme using p-aminobenzamidine affinity chromatography. J. Mol. Recognit. 19: 332-339.

41. Kumar A, bansal V, Nandakumar KS, Galaev IY, Roychoudhary PK, Holmdahl R, et al. 2006. Integrated bioprocess for the production and isolation of urokinase from animal cell culture using supermacroporous cryogel matrices. Biotechnol. Bioeng. 93: 636-646.

42. Nilsang S, Nandakumar KS, Galaev IY, Rakshit SK, Holmdahl R, Mattiason B, et al. 2007. Monoclonal antibody production using a new supermacroporous cryogel perfusion reactor. Biotechnol. Prog. 23: 932-939.

43. Kumar A, Bansal V, Andersson J, Roychoudhary PK, Mattiason B. 2006. Supermacroporous cryogel matrix for integrated protein isolation. Immobilised metal affinity chromatographic purification of urokinase from cell culture broth of human kidney cell line. J. Chromatogr. A 1103: 35-42.

44. Lozinsky VI, Galaev IY, Plieva FM, Savina IN, Jungvid H, Mattiason B. 2003. Polymeric cryogels are promising materials of biotechnological interest. Trends Biotechnol. 21: 445-451.

45. Xavier Guliherme EP, Olivia JP, Carvalho LM, Brandi IV, Sausa Santos SH, Carvalho G P, et al. 2017. Synthesis of supermacroporous cryogel for bioreactors continuous starch hydrolysis. Electrophoresis 38: 2940-2946.

46. Cadwell J, Whitford W. 2011. The potential application of hollow fiber bioreactors to large scale production: a hollow fiber matrix can be used for large scale cell culture and allows for efficient harvest of secreted proteins. Biopharm Int. 24: 21-26.

47. Akhondi E, Zamani F, Han Tng K, Leslie G, Krantz WB, Fane A G, et al. 2017. The performance and fouling control of submerged hollow fiber systems: a review. Appl. Sci. 7: 765.

48. Chotteau V, Clinke M, Eolleryd CM, Zhang Y, Lindskog E, Walsh K, et al. 2013. Very high density of CHO cells in perfusion by ATF or TFF in WAVE bioreactorTM. Part I. effect of the cell density on the process. Biotechnol. Prog. 29: 754-767.

49. Pörtner R. Platas OB, Fassnachtl D, Nehring D, Czermak P, Markl H. 2007. Fixed bed reactors for mammalian cells: design, Performance and scale up. Open Biotechnol. J. 1: 41- 46.

50. Detzel C J, Van wie B J, Ivory C F. 2010. Fluid flow through a High cell density fluidized bed during centrifugal bioreactor culture. Biotechnol. Prog. 26: 1014-1023.

51. Kumar A, Jain E. 2016. Supermacroporous Cryogels: Biomedical and Biotechnological applications. pp. 418-439. st $^{\text {st }}$ Ed. Polymer science. India.

52. Li F, Vijayasankaran N, Shen AY, Kiss R, Amanullah A. 2010. Cell culture processes for monoclonal antibody production. MAbs 5: 466-479.

53. O'Callaghan PM, James C. 2008. Systems biotechnology of mammalian cell factories. Brief. Funct. Genomic. Proteomic 7: 95-110.

54. Xu S, Gavin J, Jiang R, Chen H. 2017. Bioreactor productivity and media cost comparison for different intensified cell culture processes.Biotechnol. Prog. 33: 867-878.

55. Tapia F, Ramirezza VR, Genzel Y, Reich U. 2016. Bioreactors for high cell density and countinuous multistage cultivations: options for process intensification in a cell culture based viral vaccine production. Appl. Microbiol. Biotechnol. 100: 2121-2132.

56. Hatti-Kau R, Pereira Jr N, Diegel O, Belgrano F S. 2018. Cell immobilization on 3D-printed matrices: a model study on propionic acid fermentation. Bioresour. Technol. 249: 777-782

57. Ali C, Jackson R, Bayrak E F, Wang T, Coufal M, Undey C. 2018. High performance agent-based modeling to simulate mammalian cell culture bioreactor. Comput. Aided Chem. Eng. 44: 1453-1458.

58. Robert F Steinhoff, Daniel J Karst, Fabian Steinebach, Marie R G Kopp, Gregor W Schmidt, Alexander Stettler, et al. 2015. Microarray-based MALDI-TOF mass spectrometry enables monitoring of monoclonal antibody production in batch and perfusion cell cultures. Methods 104: 33-40

59. Hogiri T, Tamashima H, Nishizawa A, Okamoto M. 2018. Optimization of a pH- shift control strategy for producing monoclonal antibodies in Chinese hamster ovary cell cultures using a pH-dependent dynamic model. J. Biosci. Bioeng. 125: 245-250.

60. Kishishita S, Katayama S, Kodaira K, Takagi Y, Matsuda H, Okamoto H, et al . 2015. Optimization of chemically defined feed media for monoclonal antibody production in Chinese hamster ovary cells. J. Biosci. Bioeng. 120: 78-84.

61. Zhang Y, Veronique C. 2015. Observation of Chinese Hamster Ovary Cells retained inside the non-woven fiber matrix of the CellTank bioreactor. Data Brief 5: 586-588.

62. Kreyer S, Stahn R, Navrath K, Goralczyk V, Zoro B, Goletz S. 2019. A novel scale-down mimic of perfusion cell culture using sedimentation in an automated microbioreactor (SAM). Biotechnol. Prog. 35: 2832.

63. Restaino OF, Climini D, Rosa MD, Catapano A, schiraldi C. 2011. High cell density cultivation of Escherichia coli K4 in a microfiltration bioreactor: a step towards improvement of chondroitin precursor production. Microb. Cell Fact. 10: 10.

64. Bartolo LD, Salerno S, Curcio E, Piscioneri A, Rende M, Morelli S, et al. 2009. Human hepatocyte functions in a crossed hollow fiber membrane bioreactor. Biomaterials 30: 2531-2543.

65. Wang S, Godfrey S, Radoniqi F, Lin H, Coffman J. 2018.Larger pore size hollow fiber membranes as a solution to the product retention issue in filtration based perfusion bioreactors. Biotechnol. J. 14: e1800137.

66. Pérez M S, Penaherrera A, Sierra-Rodero M, Vega M, Rosero G, Lerner B, et al. 2015. Evaluation of cell culture in micro fluidic chips for application in monoclonal antibody production. Microelectron. Eng. 158: 126-129.

67. Jain E, Kumar A. 2013. Disposable polymeric cryogel bioreactor matrix for therapeutic protein production. Nat. Protoc. 8: 821-835.

68. Bray LJ, Secker C, Murekatete B, Sievers J, Binner M, Welzel PB, et al. 2018. Three-dimensional in vitro hydro- and cryogel-based cell-culture models for the study of breast-cancer metastasis to bone. Cancers 10: 292.

69. Zhang G, Song X, Mei J, Wang L, Yu L, Xing MM Q, Qiu X. 2017. A simple 3D cryogel co-culture system used to study the role of CAFs in EMT of MDA-MB-231 cells. RSC Adv. 7: 17208-17216.

70. Jyoti K, Kumar A. 2017. Development of polymer based cryogel matrix for transportation and storage of mammalian cells. Sci. Rep. 7: 41551 .

71. Westbrook A, Scharer J, Moo-Young M, Oosterhuis N, Chou CP. 2014. Application of a two-dimensional disposable rocking bioreactor to bacterial cultivation for recombinant protein production. Biochem. Eng. J. 88: 154-161. 